\title{
亜音速失速領域近傍におけるガスタービン圧縮機翼の非定常振動*
}

\author{
山口 和幸 ${ }^{* 1}$, 高橋 康雄 ${ }^{* 2}$
}

\section{Unsteady Vibration of Gas Turbine Compressor Blade at Subsonic Near-Stall Conditions}

\author{
Kazuyuki YAMAGUCHI ${ }^{* 1}$ and Yasuo TAKAHASHI \\ ${ }^{* 1}$ Hitachi Research Laboratory, Hitachi Ltd. \\ Horiguchi 832-2, Hitachinaka, Ibaraki, 312-0034 Japan
}

\begin{abstract}
A cascade wind tunnel test was conducted to evaluate an unsteady blade vibration at near stall condition quantitatively. Blade vibration stress and pressure fluctuation on the blade were measured, and damping ratio of the blade vibration in a flow was measured using the sweep excitation method and operational modal analysis. Moreover, flow excited blade vibration and aerodynamic damping ratio were calculated using three-dimensional computational fluid dynamics and three-dimensional structural finite element method. The experiments showed that discrete low frequency components are dominant in a pressure fluctuation, and a natural frequency component excited by a random fluid force is dominant in the blade vibration. The calculations showed those phenomena occur in the calculation results. The calculation error of pressure amplitude was $18 \%$, and the calculated stress amplitudes were from half to twice of measured. On the other hand, the experiments showed that the damping ratio increases as the Mach number increases, and the damping ratio measured using operational modal analysis is equivalent to that using sweep excitation. The calculated damping ratios were about 1.7 times larger than the measured. The flutter calculations showed that the damping ratio of a bending vibration mode is positive and the vibration system is stable.
\end{abstract}

Key Words : Gas Turbine, Compressor, Blade, Flow Induced Vibration, Stall, Flutter, Random Vibration, Damping

\section{1. 緒言}

地球温暖化防止の観点から二酸化炭素排出量削減は世界各国の重要な課題であり，発電事業においては高効率 コンバインドサイクルプラントの核となるガスタービンの更なる高効率化が求められている．さらに，燃料費の 高騰, 発電事業自由化にともなう市場競争激化を受けて発電機器のコスト低減が求められており, コンパクト・ 大容量ガスタービンのニーズが増加している．また，環境問題への関心の高まりから出力変動の大きい自然エネ ルギ発電設備が増加しており, 電力システムの出力調整機能を担うガスタービンには運用負荷範囲の拡大が求め られている。

このような背景のもとガスタービン圧縮機の翼においては，高効率化のための薄翼化，コンパクト・大容量化 のための高負荷化により振動応力が増加する傾向にある. 特に高圧段翼においては, 運用負荷範囲拡大にともな い部分負荷運転時の入射角が増大し，失速領域近傍で運転されることがある．この結果，乱流励振や渦励振など の非定常励振力による強制振動や, 自励振動現象である失速フラッタに対する設計余裕が減少する傾向にある.

失速領域近傍における翼振動に関寸る研究は 1980 年頃から行なわれている. 時末らは楕円翼の動的失速に対す る数值解析および実験を行ない, 剥離流れや渦放出周波数について調査した ${ }^{(1) \sim(4)}$. Abdel-Rahim らは二次元渦法

\footnotetext{
* 原稿受付 2013 年 3 月 27 日

${ }^{* 1}$ 正員, (株) 日立製作所日立研究所（テ312-0034 茨城県ひたちなか市堀口 832-2）

*2 (株) 日立製作所日立研究所

E-mail: kazuyuki.yamaguchi.jg@hitachi.com
} 
によるフラッタ解析を行ない，ねじり振動モードでは失速領域の伝播周波数と固有振動数の同期により失速フラ ッタが発生するが，曲げ振動モードでは両者は同期せず強制振動であるバフェッティングが発生することを示し た ${ }^{(5)}$. 西澤らは二次元失速フラッタ解析および実験を行ない，旋回失速と翼振動の同期により失速フラッタが発 生することを示した ${ }^{(6)(8)}$. Svensdotter らは失速領域近傍における振動翼面の圧力と翼近傍の非定常流速を計測し, 入射角の増加により層流から乱流に遷移寸ることを確認した ${ }^{(9)}$. Ellenberger らは遷音速ねじりフラッタ発生時の 流れ場を油膜法とシュリーレン法を用いて可視化した ${ }^{(10)}$. Weber らは準三次元モデルによるねじり失速フラッタ 解析を行なった ${ }^{(11)}$. 低入射角における定常，非定常流れ解析結果は実測結果と良く一致したが，高入射角では翼 前縁付近における負減衰効果を予測できなかった。 青塚らは二次元の失速フラッタ解析 ${ }^{(12)}$, 高亜音速時のねじり 失速フラッタに対する実験と準三次元モデルによる解析 ${ }^{(13)(14)}$ を行なうとともに, 三次元の失速フラッタ解析 ${ }^{(15)}$ を行ない，翼前縁における剥離泡が翼振動特性を支配することを示した．Johann らは高速多段圧縮機動翼の亜音 速ねじりフラッタ発生時における振動ひずみを計測するとともに一翼振動法による空力減衰比解析を行ない，ね じりフラッタは発生するが曲げフラッタは発生しないことを確認した ${ }^{(16)}$.

上述のように，自励振動である放じり失速フラッタに関する多数の報告があり(1) (16), また流体加振力として， 渦励振 $(1) \sim(8)(11)(14)$ や乱流励振 ${ }^{(9)}$ に関寸る報告も見受けられる. しかし, 失速領域近傍における乱流励振や渦励振な どの流体力や翼振動の解析精度の定量評価に関する報告はほとんど見られない. 一方, 空力減衰は翼振動応答を 評価する上で重要であり, 特にフラッタを生じやすい㸚じり振動モードの空力減衰に関する多数の報告があ る(6) (9)(11) (16). しかし, 強制振動においてねじり振動モードとともに重要な曲げ振動モードの空力減衰に関する 報告はほとんど見られず，Johann ら ${ }^{(16)}$ の解析においても精度検証はなされていない.

そこで本研究では失速領域近傍における非定常翼振動の定量予測を目的として, 翼列風洞実験により非定常翼 振動応力および翼面圧力変動を計測するとともに, 三次元非定常数值流体解析（CFD 解析）と三次元構造有限要 素解析（構造 FEM 解析）を連携させた非定常翼振動応答解析を行ない，その有効性を検証した，一方，翼に貼 り付けた圧電素子を用いたスウィープ加振による翼振動減衰比計測を行なうとともに，実機計測に適用できる非 加振の実稼働モーダル解析（OMA）による減衰比計測を行ない，その有効性を検証した．また，固有振動モード で翼を強制加振する CFD 解析により空力減衰を計算し, 計測結果との比較を行なった.

\section{2. 実験方法}

本研究では, 流れ中の非定常圧力と振動ひずみの計測, 圧電素子を用いたスウィープ加振による減衰比計測, および非加振の OMA による減衰比計測を行なった. 図 1 に試験翼列を, 図 2 に翼列風洞を示寸. 翼列風洞に試 験翼列を設置し, 空気流れ中の翼振動現象を計測した. 入口マッ八数は $0.35 \sim 0.55$, 入射角は-3 $\sim 70$ とした. 試 験翼列は 7 枚の翼で構成されており, 中央の翼は片持ち支持の試験翼, その他の翼は両持ち支持の固定翼である.

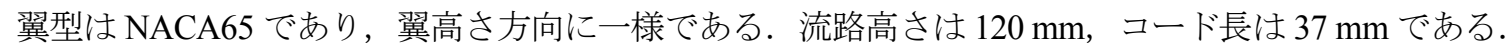

図 3 に試験翼を示寸．翼背側の根元後縁付近に圧電素子を貼り付け，翼の加振に利用した．一方，翼腹側の根 元付近にひずみゲージ（共和電業製 KFR-2-120-C1-16）を貼り付け，翼振動を計測した．動ひずみアンプには共 和電業製 DPM-713B を使用し，前縁側ひずみにヤング率を掛けた応力を評価した．また，翼背側の流路高さ，ス パン方向中央部にはひずみゲージ式圧力センサ（Kulite 製 LE-062-35A）を埋め込み，圧力変動を計測した． 圧力 計用の直流アンプには Unipulse 製 AM32AZ を使用した. 圧電素子とひずみゲージの流れに対する影響を排除す るために，試験翼の根元部を翼高さ方向に流路から $20 \mathrm{~mm}$ 延長した．なお，試験翼の材質は SUS304 である.

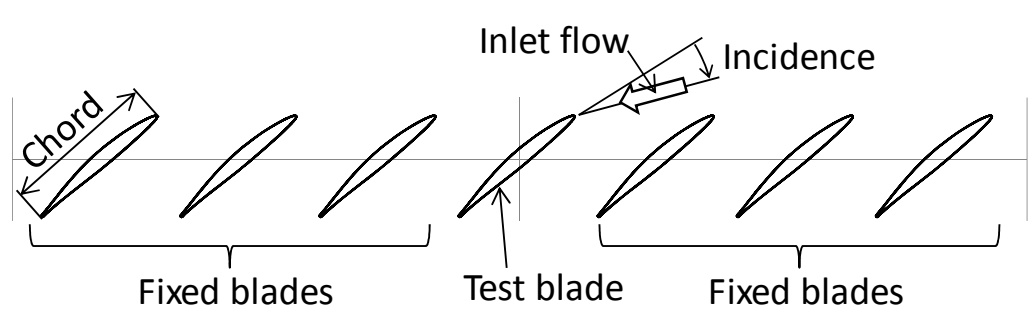

Fig. 1 Test cascade 
スウィープ加振試験では，非定常流体力による振動と比較して十分に大きな加振振動応答が得られなかったた め, 各周波数において加振信号に基づく約 40 回の同期平均処理を行なうことにより計測ノイズを低減した.また, 加振周波数を逐次変化させることにより得られた周波数応答関数に対してカーブフィットを施すことにより減衰 比を算出した。一方, OMA は非定常流体力による振動応答をランダム振動応答とみなして実験モーダル解析を 行なう手法である. 計測精度を向上するために比較的長時間のデータが必要であり，有次元のモーダル量を得ら れないが, 加振の必要が無いことから実機の振動減衰評価への適用が期待される. OMA には LMS Test. lab REV 10B ${ }^{(17)}$ (LMS Test. lab は LMS International の登録商標）を使用し，約 120 秒の時間波形データを分析した.

\section{3. 解析方法}

\section{$3 \cdot 1$ 非定常振動応答解析方法}

非定常翼振動応力は，CFD 解析により算出した翼面流体力変動を構造 FEM 解析に入力することにより計算し た. CFD 解析には ANSYS CFX Release 13.0 (18) (ANSYS CFX は SAS IP, Inc.の登録商標）を，構造 FEM 解析には ANSYS Release 13.0 ${ }^{(19)}$ (ANSYS はSAS IP, Inc.の登録商標）を使用した. 図 4 は CFD 非定常流体力解析モデルで ある. 試験翼 1 枚分の流路をモデル化し，翼先端間隙を考慮した．翼列方向の境界条件は周期境界とし，入口境 界条件として全温, 全圧, 流れ方向を, 出口境界条件として静圧を与えた. 流体は理想気体の空気とし, 乱流モ デルには LES Dynamic Model を, 移流スキームには Central Difference 法を, 過渡スキームには Second Order Backward Euler 法を使用した。要素数は約 270,000 であり，時間刻みは $2.5 \times 10^{-5} \mathrm{~s}$ とした，解析結果として各時間 ステップにおける翼面節点の流体力を出力した.

図 5 は構造 FEM 解析モデルである. 翼根元部を完全固定とした. 要素にはソリッド一次要素を用い, 翼厚さ 方向に 8 分割した. 要素数は約 18,000 であり, 解析時間刻みは $1.0 \times 10^{-4} \mathrm{~s}$ とした. また, 減衰モデルには比例粘 性減衰を採用し，1 次および 2 次固有振動モードの減衰比が後述する OMA の実測結果と一致するように質量比 例定数および岡性比例定数を決定した.

\section{$3 \cdot 2$ 空力減衰解析方法}

\section{（1）数値解析方法}

試験翼のみが振動する場合の単翼減衰比は，1 枚の試験翼を単一の固有振動数, 固有振動モードで加振したと きの空力仕事をもとに計算した。また，翼列フラッタ減衰比は一翼振動法 ${ }^{(12)} に よ り$ 算出した. 翼振動の固有值解 析には図 5 の解析モデルを使用し, 解析結果として固有振動数, 固有振動モード変位, および振動 1 周期におけ る最大運動エネルギを出力した. 図 6 は CFD 空力減衰解析モデルである. 試験翼列では 7 枚の翼を採用したが, 解析時間短縮のために空力減衰に対する影響が大きい試験翼とその両隣の 3 枚の翼をモデル化し, 試験条件と同 様に試験翼のみを振動させた. 振動振幅の最大值は約 $60 \mu \mathrm{m}$ とした. 要素数は約 800,000 であり, 解析時間刻み

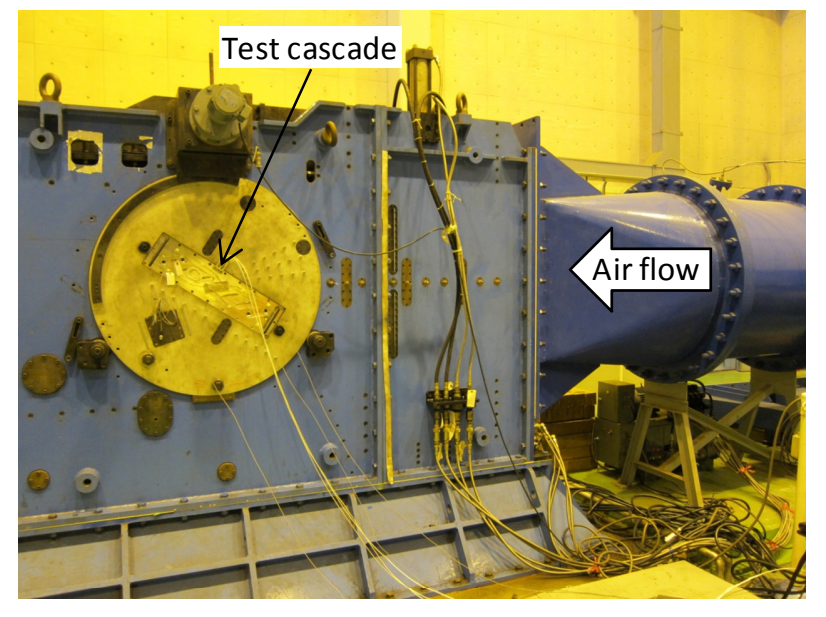

Fig. 2 Wind tunnel

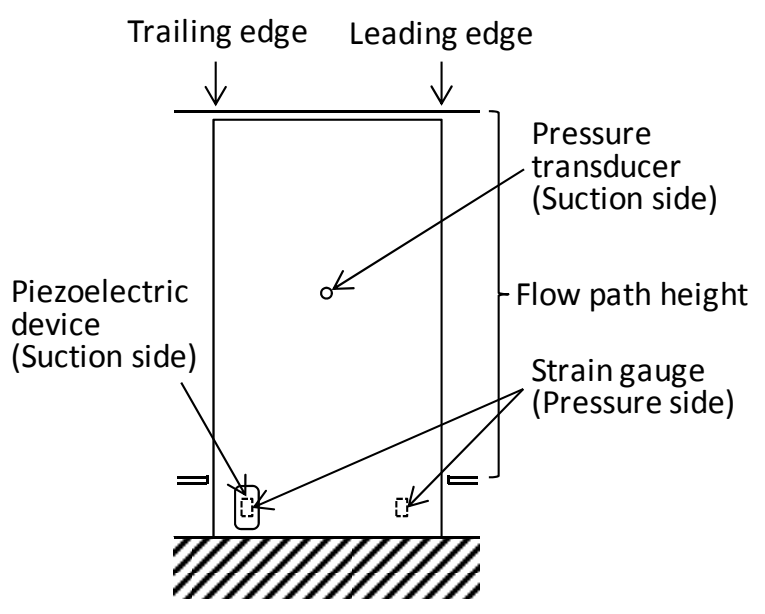

Fig. 3 Test blade 
は固有振動周期の 1/64 とした. また, 乱流モデルは Shear Stress Transport とした. 解析結果として各時間ステッ プにおける翼面節点の流体力および变位を出力した，その他の解析条件は $3 \cdot 1$ 節と同様である.

\section{（2）単翼空力減衰比計算方法}

翼面節点 $i$ における変位振幅を $X_{i}, Y_{i}, Z_{i}$, 流体力振幅を $F_{x i}, F_{y i}, F_{z i}$ とし, 各方向変位を基準にした流体力位 相を $\varphi_{x i}, \varphi_{y i}, \varphi_{z i}$ とする. 振幅および位相は時刻歴波形に対して高速フーリエ変換を施すことにより得られる. 単 翼の空力仕事 $W$ は，試験翼表面の節点数を $n$ として次式で表される.

$$
W=\pi \sum_{i=1}^{n}\left\{F_{x i} X_{i} \sin \left(\varphi_{x i}\right)+F_{y i} Y_{i} \sin \left(\varphi_{y i}\right)+F_{z i} Z_{i} \sin \left(\varphi_{z i}\right)\right\}
$$

一方，翼振動のモーダル質量を $M$, 流体力によるモーダル粘性減衰係数を $C$, モーダルばね定数を $K$, 固有角 振動数を $\omega$, モーダル変位振幅を $\Psi$ とすると, 振動 1 周期の空力仕事 $W$, 振動 1 周期における最大運動エネルギ

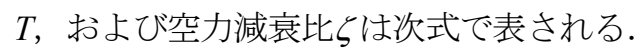

$$
\begin{aligned}
& W=-\pi \omega C \Psi^{2} \\
& T=\frac{1}{2} M \omega^{2} \Psi^{2} \\
& \zeta=\frac{C}{2 \sqrt{M K}}=-\frac{1}{4 \pi} \frac{W}{T}
\end{aligned}
$$

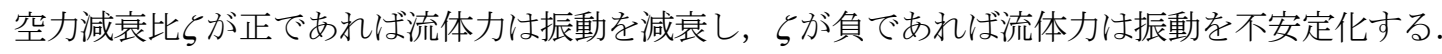

\section{（3）翼列フラッタ空カ減衰比計算方法}

翼列フラッタの空力仕事を一翼振動法により計算する. 振動が翼列方向の上流側から下流側に伝播するときの 翼間位相差 $\beta$ を正とする. 図 6 に示すように, 翼番号 $j$ を翼列方向上流側から-1，0，+1 とする. 翼 0 を加振した ときに, 翼+1 では上流側翼の振動による流体力変動が, 翼-1 では下流側翼の振動による流体力変動が観測される. 従って, 翼列が翼間位相差 $\beta$ で振動するときの，当該翼と隣接翼の振動による空力仕事は次式で計算できる.

$$
W=\pi \sum_{j=-1}^{+1} \sum_{i=1}^{n}\left\{F_{x i j} X_{i} \sin \left(\varphi_{x i j}-j \beta\right)+F_{y i j} Y_{i} \sin \left(\varphi_{y i j}-j \beta\right)+F_{z i j} Z_{i} \sin \left(\varphi_{z i j}-j \beta\right)\right\}
$$

ただし，添え字 $j$ は翼 0 を振動させたときの翼 $j$ の流体力解析結果を表す. 式（5）の空力仕事を式（4）に代入 することにより翼列フラッタの空力減衰比を計算できる.
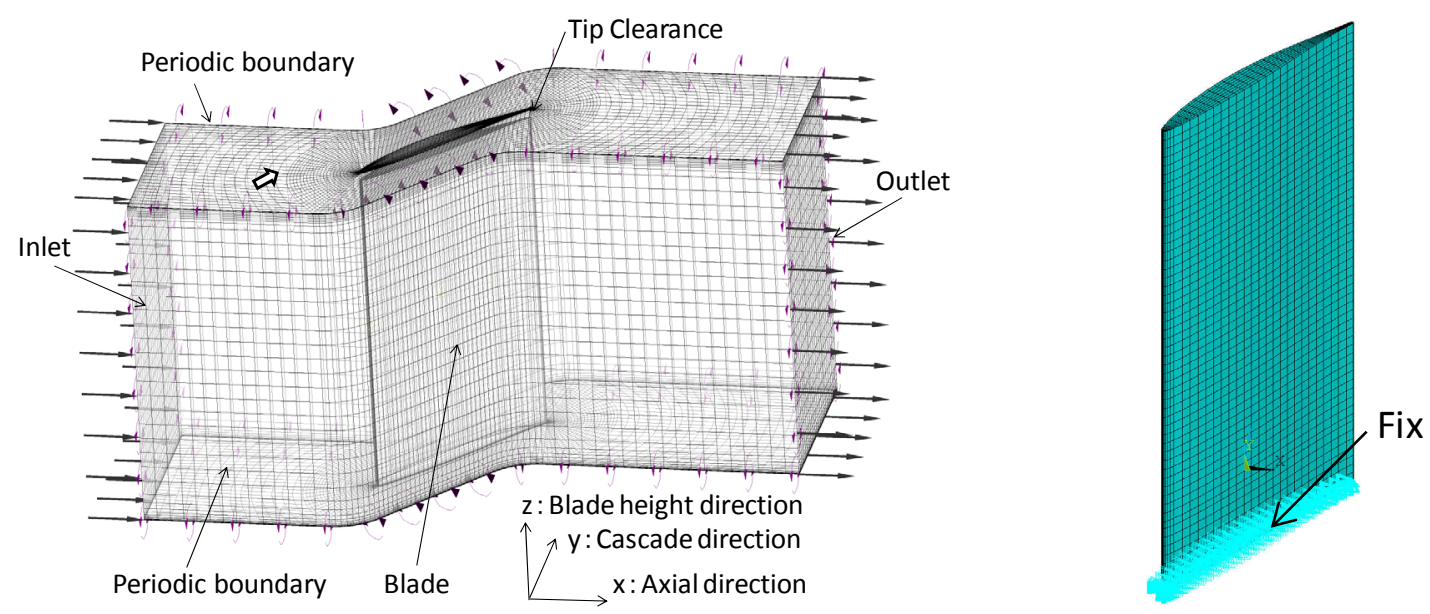

Fig. 4 CFD calculation model for unsteady response

Fig. 5 Structural FEM calculation model for blade vibration 


\section{4. 結 果}

\section{$4 \cdot 1$ 非加振時の非定常振動}

固有振動モード計算結果を図 7 に示す. 固有振動モードは低次側から曲げ 1 次振動モード，㸚じり 1 次振動モ ード，曲げ 2 次振動モードの順に現れる.

図 8 は翼面圧力変動および翼振動応力の周波数スペクトル計測結果である. 上側 3 図は入射角 $2^{\circ}$ のきの結果, 下側 2 図は入口マッ八数 0.48 のときの結果である. 図 8 (a) の圧力変動を見ると $200 \mathrm{~Hz}$ 以下の離散低周波成分 が支配的であり，固有振動数を含む $200 \mathrm{~Hz}$ 以上の周波数領域では乱流励振による広帯域のランダム成分が現れて いる．一方，図 8 （b）の振動応力を見ると乱流励振力との共振による 1 次固有振動数成分（263 Hz）が支配的 であり，2 次固有振動数成分 $(1,190 \mathrm{~Hz})$ および 3 次固有振動数成分 $(1,590 \mathrm{~Hz})$ も僅かに現れている. これらの 固有振動モードは図 7 に示寸解析結果に対応していると推定される．また，圧力変動において支配的な離散低周 波成分は，流体力が大きくなる高入口マッ八数条件において振動応力にも現れている.

図 9 は圧力振幅および応力振幅の計測結果である. 図には計測ばらつきをエラーバーで表示している. 図 9 (a) に示寸圧力振幅は入口マッ八数の増加，入射角の増加により増加する傾向にある．同様に，図 9 (b) の応力振幅 も入口マッ八数, 入射角の増加により増加している.

なお, 入射角-3における圧力振幅は入口マッ八数 0.46 付近でピークを示している. このときの圧力変動の周波 数スペクトルを確認したところ $73 \mathrm{~Hz}$ および $145 \mathrm{~Hz}$ の離散低周波成分が選択的に増加していた。一方，応力振幅 では入口マッ八数 0.46 付近におけるピークは見られないことから, 入口マッ八数 0.46 付近では音響共鳴が発生し ている可能性が考えられる．具体的な音響モードの特定のためには音圧分布の計測が必要であるが，本試験条件 における空気の音速は約 $380 \mathrm{~m} / \mathrm{s}$ であることから $73 \mathrm{~Hz}$ の音響モードの波長は約 $5.2 \mathrm{~m}$ と長いため, 試験翼列では なく風洞の流路に起因した音響モードが発生していると考えられる.

図 10 は入口マッ八数 0.48 , 入射角 70 における翼面圧力変動および翼振動応力の過渡応答解析結果であり, 図 8 の最下図の条件に対応する. CFD 解析では定常解析結果を初期值として 10,240 ステップの解析を行ない, 計算開 始時の過渡応答を排除するために後半の 4,096 ステップのデータを評価した. 構造FEM解析ではCFD 解析の 2,046 〜10,240 ステップ（CFD 解析の評価ステップの 2 倍）における流体力計算結果を 4 ステップおきに使用し，計算 開始時の過渡応答排除のために構造 FEM 解析結果における後半 1,024 ステップの計算結果を評価した. 図 10 (a) の圧力変動を見ると離散低周波成分が支配的であること， $200 \mathrm{~Hz}$ 以上の周波数領域においては広帯域のランダム 成分が現れていることから，図 8 (a) で計測された流動現象を再現できていると考える. 解析結果における離散 低周波成分は $59 \mathrm{~Hz}, 1.17 \mathrm{kPa}$ ，実駼結果における離散低周波成分は $93 \mathrm{~Hz} ， 0.99 \mathrm{kPa}$ であり，周波数は若干異な るものの振幅は誤差 $18 \%$ で良好に一致している.

図 10 (b) の振動応力解析結果を図 8（b）の計測結果と比較すると，1 次固有振動数成分が最も大きく，この ほかに 2，3 次固有振動数成分および離散低周波成分が現れており，現象を再現できていると考える. 1 次固有振 動数成分の計算結果は計測結果の $1 / 2$ 程度，離散低周波成分および 2 次， 3 次固有振動数の計算結果は計測結果

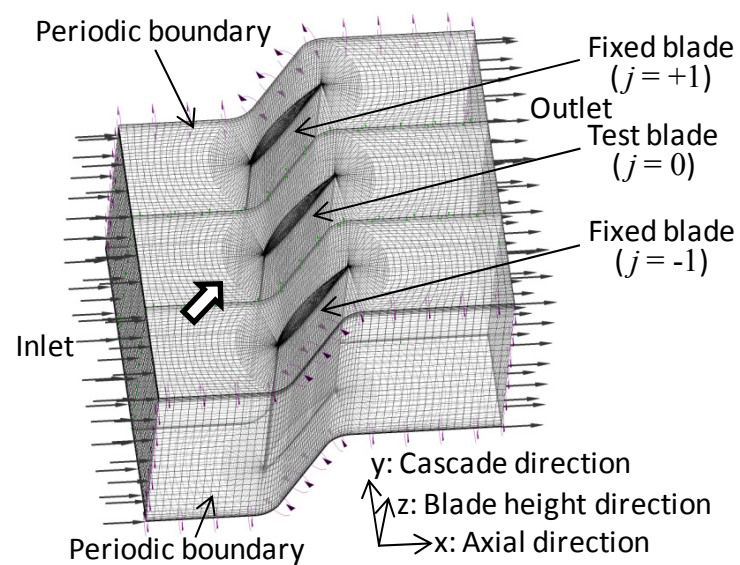

Fig. 6 CFD calculation model for aerodynamic damping

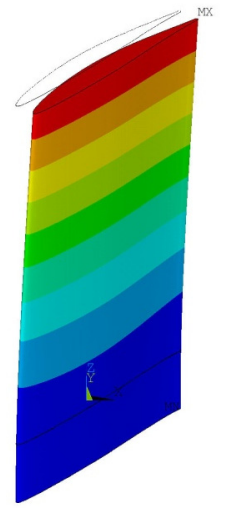

(a) Mode 1:277 Hz

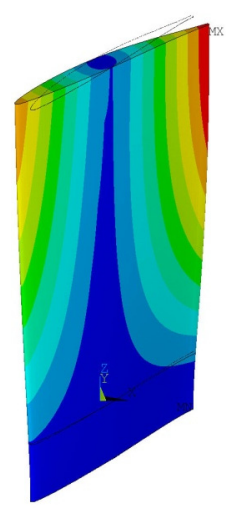

(b) Mode 2: $1215 \mathrm{~Hz}$

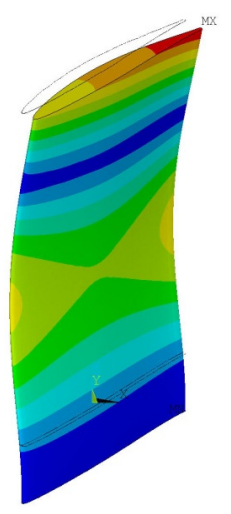

(c) Mode 3: $1672 \mathrm{~Hz}$

Fig. 7 Calculated natural vibration mode 

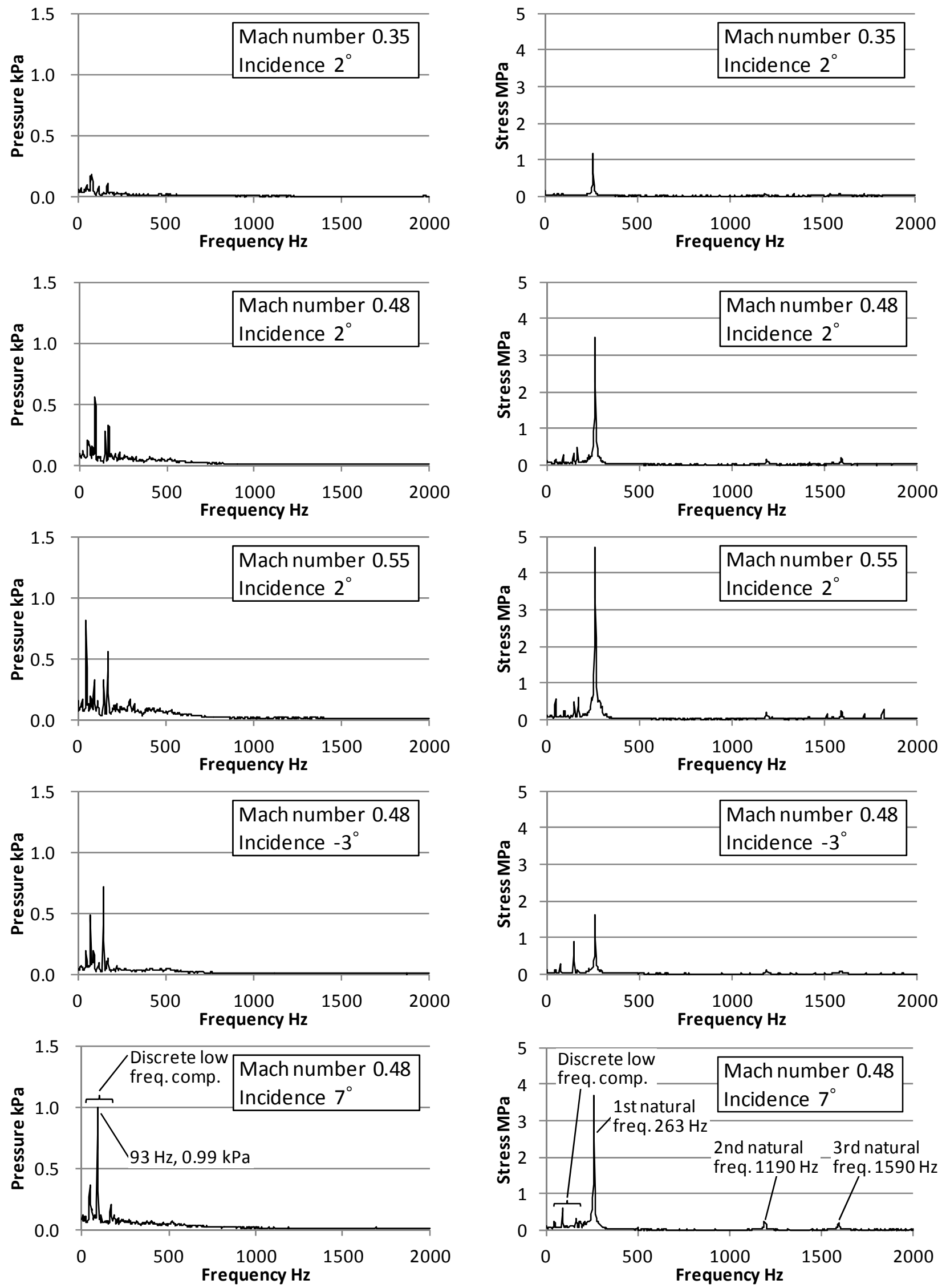

(a) Pressure

(b) Stress

Fig. 8 Frequency spectrum of measured pressure and stress 
の 2 倍程度であり，両者は概ね一致していると考える．図 10（a）の非定常圧力計算結果を見ると，評価時間が 短いため広帯域ランダム成分の振幅がばらついており，このことが図 10 (b) の振動応力計算結果における誤差 要因になっている可能性がある.

図 11 に入口マッ八数 0.48 , 入射角 $7^{\circ}$ における離散低周波成分（59 Hz）の 1 周期において，流体力が最小およ

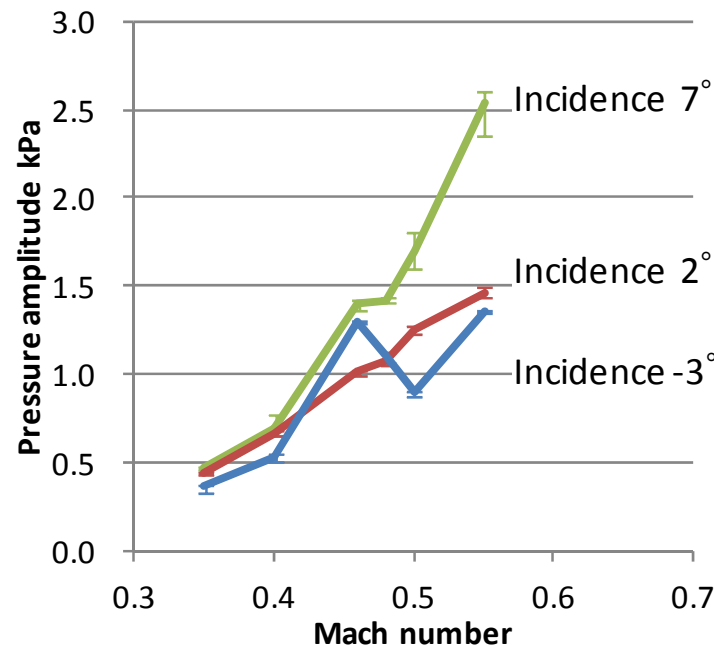

(a) Pressure

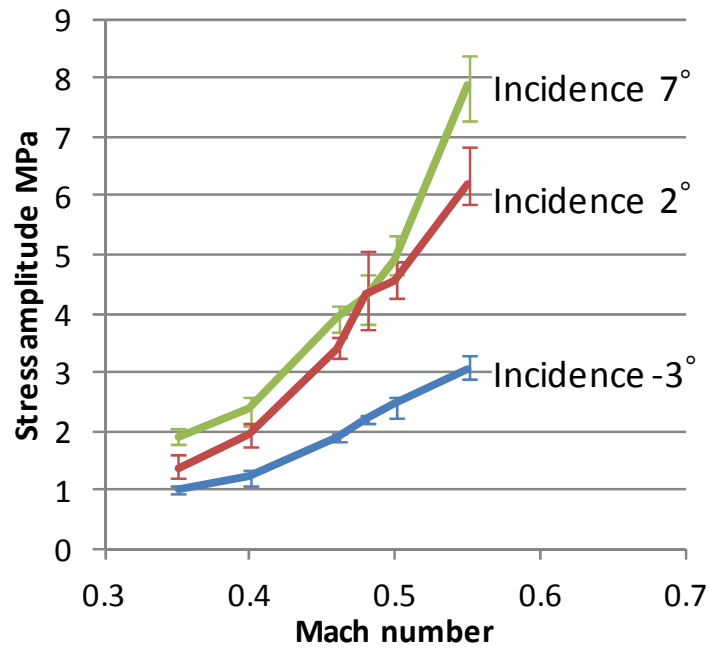

(b) Stress

Fig. 9 Amplitude of measured pressure and stress

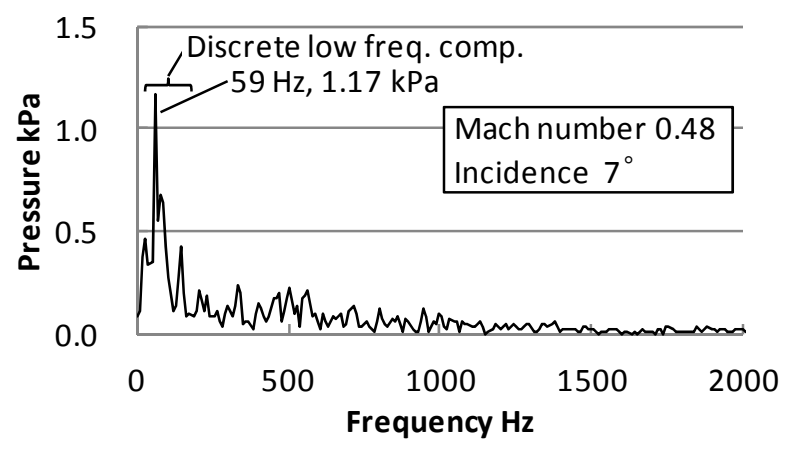

(a) Pressure

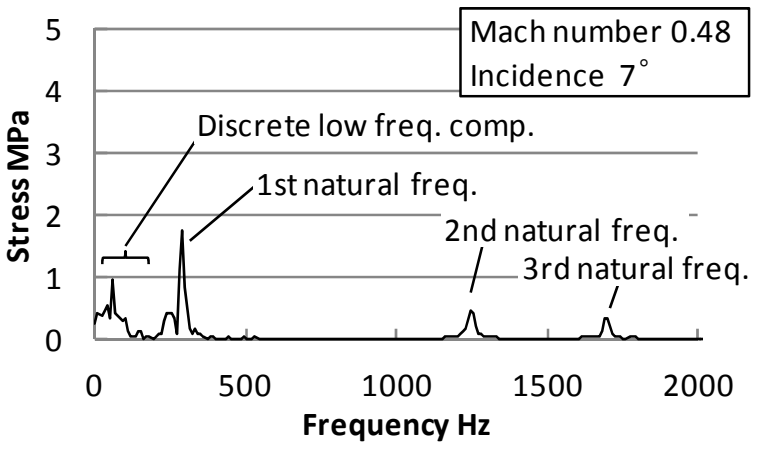

(b) Stress

Fig. 10 Calculation result of unsteady pressure and stress

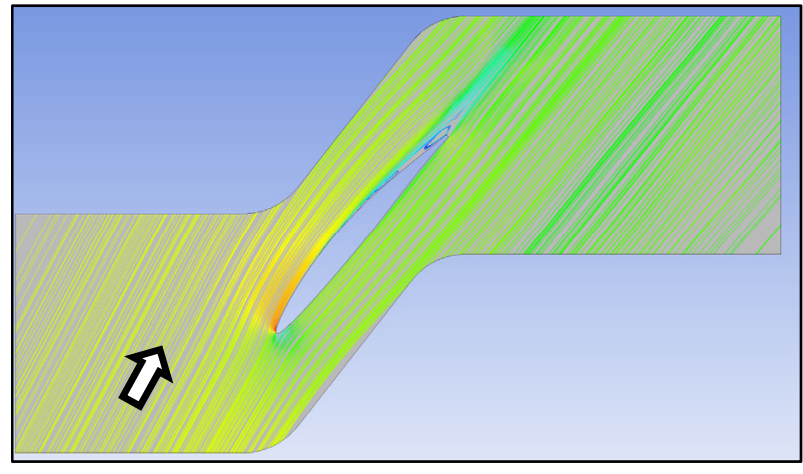

(a) When fluid force was smallest in period of low- frequency component $(59 \mathrm{~Hz})$

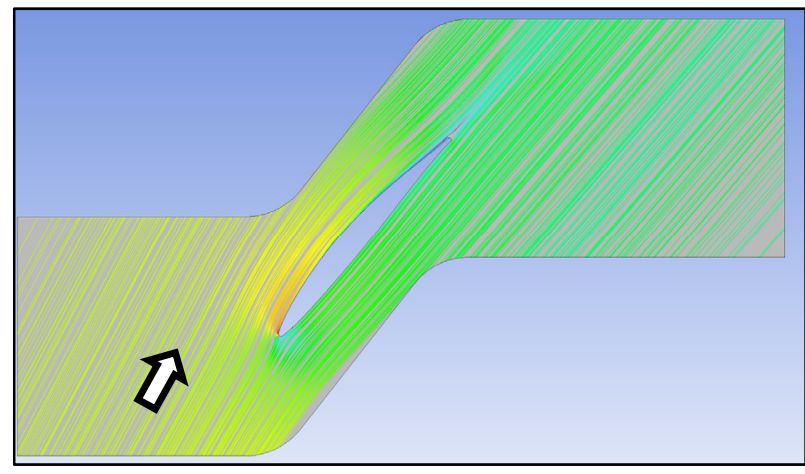

(b) When fluid force was largest in period of low-frequency component $(59 \mathrm{~Hz})$

Fig. 11 Calculation result of stream lines at mid span (Mach number 0.48, Incidence $7^{\circ}$ ) 
び最大となる時刻における翼高さ方向中央の流路断面の流線を示寸．図 11 （a）の流体力が最小となる時刻では 翼の背側後縁に渦が発生しており，図 11(b)の流体力が最大となる時刻ではこの渦が消滅している. 図 11(b)の状 態から図 11(a)の渦が発生し, この渦が成長した後, 後流側に流出し, 図 11(b)の状態に戻るという变動を繰り返 す.このように，翼の後縁における渦の発生，消滅により離散低周波成分が発生していることがわかる.

図 12 は入射角 70 においてマッ八数を変更したときの加振圧力 $p_{e}$ と全圧損失 $\Delta p_{t}$ の関係の計算結果を示す. ここ に, 加振圧力は 1 次固有振動数成分の流体加振力（固有振動数 $\pm 20 \%$ の周波数範囲の RMS 值を $\sqrt{2}$ 倍して算出） を翼コード長と流路高さで除したものである．加振圧力と全圧損失は比例関係にある．一方，加振圧力と翼振動 応力も比例関係にあることから，全圧損失と翼振動応力の比例定数を予め求めておくことにより，全圧損失を基 に翼振動応力を簡易的に推定できることがわかる.

\section{$4 \cdot 2$ 単翼の減衰比}

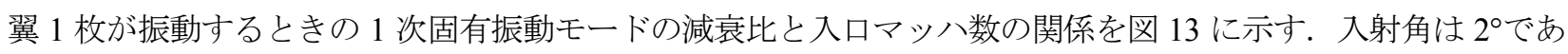
り, OMA とスウィープ加振の結果を比較している. 入口マッ八数が増加すると減衰比が増加する傾向にある. また, スウィープ加振では加振力が十分に得られなかったためばらつきが大きくなっている．ばらつきの中央值 を比較すると OMA とスウィープ加振の結果は同等であり, 非加振の OMA を流れ中の翼の減衰評価に適用でき ることがわかる。

図 13 には単翼減衰比の解析結果も示している. 本解析では 512 ステップの解析を行ない, 安定した正弦波とな る後半の 256 ステップのデータを評価した. 実験結果と同様に, 入ロマッ八数の増加にともない減衰比が増加す る傾向にあるが, 解析結果は実験結果に対して若干大きめの結果となっており, OMA の結果に対して約 1.7 倍と なっている. 解析メッシュが粗いことによる数值粘性の影響により, 解析では流体力を過大評価している可能性 がある。

図 14 は OMA による減衰比計測結果であり，図14（a）および図 14（b）はそれぞれ 1 次および 2 次固有振動 モードの結果を示す. 1 次固有振動モードでは減衰比のばらつきが大きく, 入射角の増加により減衰比が増加す る傾向にある. 一方, 2 次固有振動モードでは 1 次固有振動モードと比較して減衰比が小さく, 入射角の変化に よる減衰比の変化が小さくなっている.

\section{$4 \cdot 3$ 翼列フラッタの減衰比}

翼列が一定の翼間位相差で振動するときの 1 次固有振動モードに対する翼列フラッタ減衰比計算結果を図 15 に示す. 図 15 (a) および（b）はそれぞれ入射角 $2^{\circ}$ および 7 の結果である. 翼間位相差 10〜20付近において減 衰比が最小となり, 入ロマッ八数の増加とともに減衰比は増加寸る. 本振動モードは曲げ振動モードであるため, 隣接翼間の流路幅変化による隣接翼間の流体の増減により減衰力が発生している可能性がある. このため, 流路

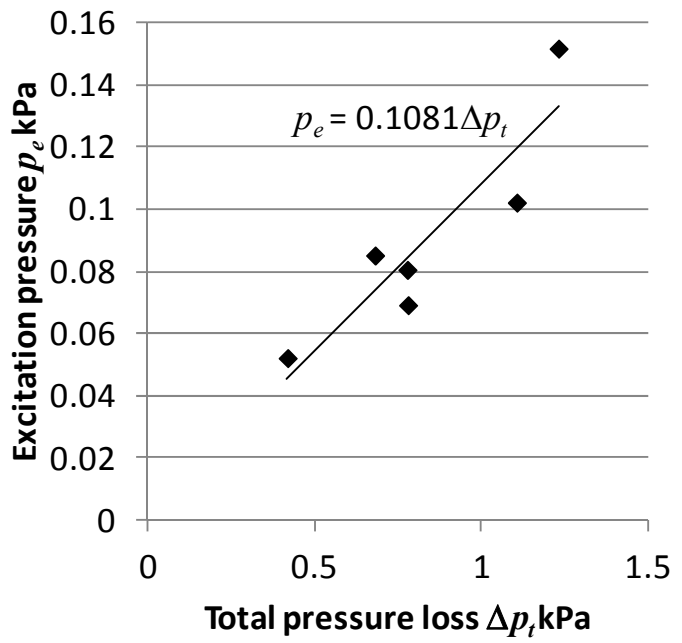

Fig. 12 Calculation result of excitation pressure (Incidence $7^{\circ}$ )

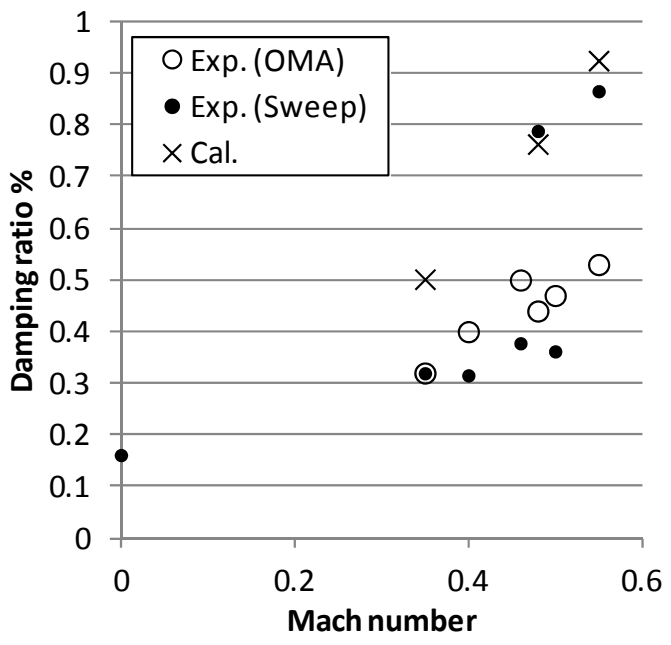

Fig. 13 Damping ratio of first mode (Incidence $2^{\circ}$ ) 


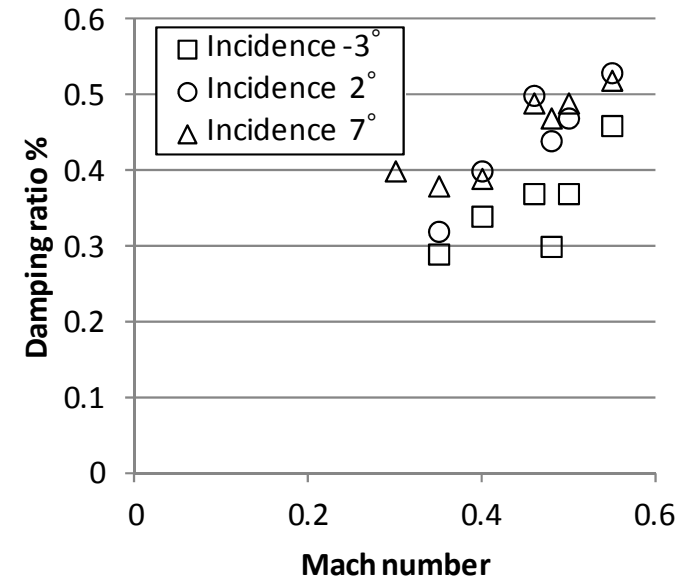

(a) Mode 1

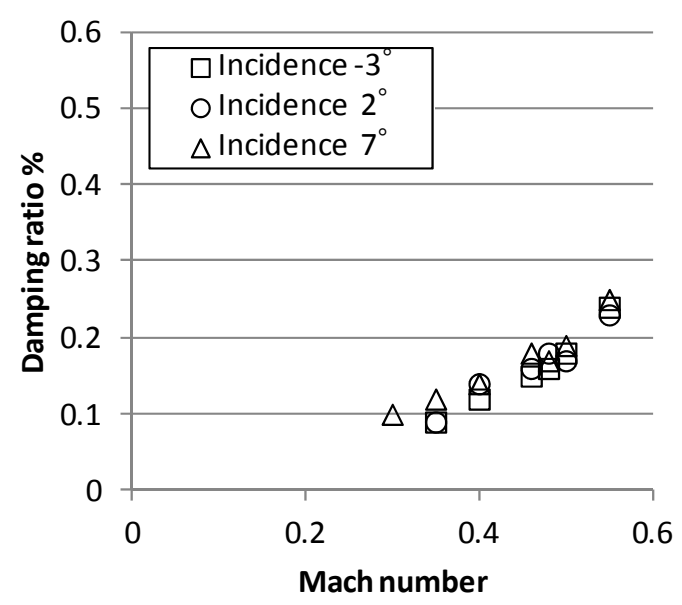

(b) Mode 2

Fig. 14 Damping ratio measured with OMA

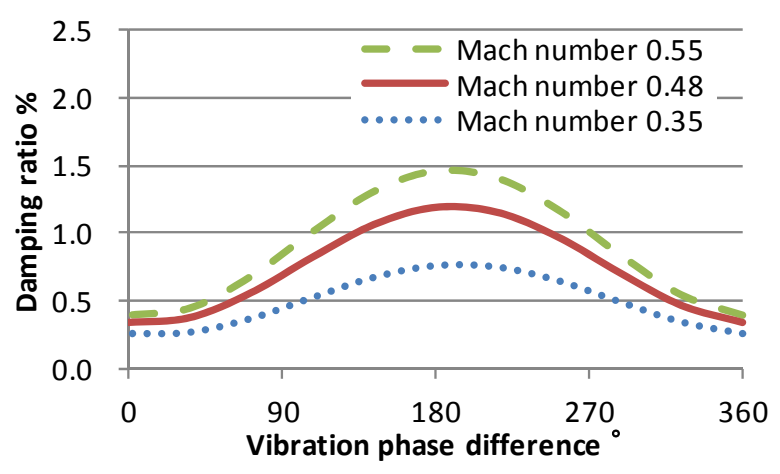

(a) Incidence $2^{\circ}$

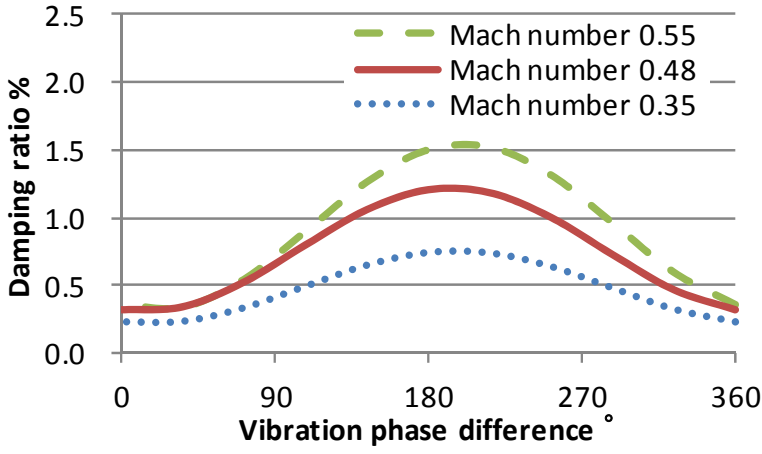

(b) Incidence $7^{\circ}$

Fig. 15 Calculation result of flutter

幅が最も変動する翼間位相差 180 付近で空力減衰が最大, 翼間流路幅変化が最小となる翼間位相差 0 付近で空力 減衰が最小になっていると考えられる，減衰比は常に正であることから，本解析条件における曲げ 1 次固有振動 モードではフラッタは発生しないことがわかる.

\section{5. 結 言}

失速領域近傍における非定常翼振動の定量予測を目的として翼列風洞実験を行ない，翼振動応力および翼面圧 力変動を計測するとともに，翼に張り付けた圧電素子によるスウィープ加振および非加振の実稼働モーダル解析 により流れ場中の翼振動減衰比を計測した. また, 三次元数值流体解析と三次元構造有限要素解析の連携により 非定常流体加振力による翼振動応答を計算するとともに, 翼を固有振動モードで加振した数值流体解析により空 力減衰比を計算し，実験結果と比較した. 本研究の結果，以下の結論を得た.

(1) 翼列風洞試験の結果, 翼面圧力变動では $200 \mathrm{~Hz}$ 以下の離散低周波成分が支配的であり, 固有振動数を含む $200 \mathrm{~Hz}$ 以上の周波数領域では乱流励振による広帯域のランダム成分となった. 翼振動応力では乱流励振力と の共振による 1 次固有振動成分が支配的であった. 振動応力および圧力変動は入口マッ八数および入射角の 増加にともない増加する傾向にあった。

（2）非定常数值解析の結果, 翼面圧力変動において離散低周波成分が発生寸ること, $200 \mathrm{~Hz}$ 以上では広帯域のラ ンダム成分となることを再現できた．また，離散低周波成分は翼背側後縁における渦の発生，消滅に起因す ることがわかった，離散低周波成分の振幅解析誤差は $18 \%$ であり，解析結果と計測結果は良好に一致した. 
一方，翼振動応力において固有振動数成分と離散低周波成分が発生することを再現できた．振動応力振幅の 解析結果は計測結果の $0.5 \sim 2$ 倍程度であり, 両者は概ね一致した.

(3) 減衰比計測結果は入口マッ八数の増加とともに増加した. 実稼働モーダル解析による減衰比計測結果はスウ ィープ加振結果と同等であり, 実稼働モーダル解析が流れ中の翼振動減衰比の評価に適用できることを確認 した.

（4）単翼の減衰比計算結果は実験結果より若干高く，実稼働モーダル解析結果の約 1.7 倍であった。 また，一翼 振動法による翼列フラッタ解析の結果, 減衰比は正であり, 入口マッ八数の増加にともない減衰比は増加す ることから，本条件における曲げ振動モードでは翼列フラッタは発生しないことがわかった.

\section{文献}

（1）時末裕允, 高田浩之, “動的失速時の翼周辺はく離流と非定常空気力に関する研究（第 1 報, 数值解析一その 1)”, 日本機械学会論文集 B 編, Vol. 50, No. 460 (1984), pp. 3124-3132.

(2) 時末裕允, 高田浩之, “動的失速時の翼周辺はく離流と非定常空気力に関寸る研究（第 2 報, 数值解析一その 2)”, 日本機械学会論文集 B 編，Vol. 50, No. 460 (1984), pp. 3133-3141.

（3）時末裕允, 高田浩之, “動的失速時の翼周辺はく離流と非定常空気力に関する研究（第 3 報, 実験）”, 日本機械学 会論文集 B 編，Vol. 55, No. 510 (1989), pp. 321-328.

(4) 時末裕允, 高田浩之, “動的失速時の翼周辺はく離流と非定常空気力に関する研究 (第 4 報, 考察) ”, 日本機械学 会論文集 B 編，Vol. 55, No. 510 (1989), pp. 329-336.

(5) Abdel-Rahim, A., Sisto, F., and Thangam, S., "Computational Study of Stall Flutter in Linear Cascades", ASME Journal of Turbomachinery, Vol. 115 (1993), pp.157-166.

(6) 西澤敏雄, 高田浩之, “数值解析による圧縮機翼列の失速フラッタに関する研究 (第 1 報, 数值解析法と計算例) ”, 日本機械学会論文集 B 編，Vol. 65, No.635 (1999), pp. 2293-2300.

(7) 西澤敏雄, 高田浩之, “数值解析による圧縮機翼列の失速フラッタに関寸る研究（第 2 報, 振動翼の非定常空力特 性と旋回失速の関係）”，日本機械学会論文集 B 編，Vol. 65, No.635 (1999), pp. 2301-2308.

（8）西澤敏雄，飯田安彦，高田浩之，“失速フラッタの翼列風洞実験”，日本機械学会論文集 B 編，Vol. 65, No.635 (1999), pp. 2309-2316.

(9) Svensdotter, S., Johansson, U., and Fransson, T., "Unstable Lift on an Oscillating Blade at Near Stall Conditions", AIAA Paper No. 98-3749 (1998).

(10) Ellenberger, K. and Gallus, H. E., "Experimental Investigations of Stall Flutter in a Transonic Cascade", ASME Paper No. 99-GT-409 (1999).

(11) Weber, S., and Platzer, M. F., "A Navier-Stokes Analysis of the Stall Flutter Characteristics of the Buffum Cascade", ASME Journal of Turbomachinery, Vol. 122 (2000), pp.769-776.

(12) 青塚瑞穂, 渡辺紀徳, 町田保男, “亜音速中における剥離を伴う二重円弧翼列の非定常空力特性”, 第 29 回ガスタ ービン定期講演会講演論文集，No. A-3 (2001), pp. 23-28.

(13) 青塚瑞穂, 渡辺紀徳, 町田保男, “剥離を伴う二重円弧振動翼列の非定常空力特性 - 高亜音速流の場合 一”, 第 30 回ガスタービン定期講演会講演論文集, No. B-25 (2002), pp. 317-322.

(14) Watanabe, T., and Aotsuka, M., "Unsteady Aerodynamic Characteristics of Oscillating Cascade with Separation Bubble in High Subsonic Flow”, ASME Paper No. GT2005-68665 (2005).

(15) 青塚瑞穂, 土屋直木, 加藤大, 堀口泰生, 山本一臣, 野崎理, “ファン遷音速失速フラッタの発生機構の数值解析”, 第 36 回ガスタービン定期講演会講演論文集, No. A-22 (2008), pp. 137-142.

(16) Johann, E., Mück, B., and Nipkau, J., "Experimental and Numerical Flutter Investigation of the 1st Stage Rotor in 4-Stage High Speed Compressor”, ASME Paper No. GT2008-50698 (2008).

(17) LMS International, "Operational Modal Analysis LMS Test.lab Rev 10A”, (2009).

(18) SAS IP, Inc., "CFX-Solver Theory Guide", (2010).

(19) SAS IP, Inc., "Theory Reference for the Mechanical APDL and Mechanical Applications", (2010). 